\title{
Erratum: Magnetic droplet nucleation boundary in orthogonal spin-torque nano-oscillators
}

Sunjae Chung, Anders Eklund, Ezio lacocca, Seyed Majid Mohseni, Sohrab R. Sani, Lake Bookman, Mark A. Hoefer, Randy K. Dumas \& Johan Åkerman

Nature Communications 7:11209 doi: 10.1038/ncomms11209 (2016); Published 18 Apr 2016; Updated 12 May 2016

The affiliation details for Mark A. Hoefer are incorrect in this Article. The correct affiliation details for this author are given below: Department of Applied Mathematics, University of Colorado, Boulder, Colorado 80309-0526, USA. (c) This work is licensed under a Creative Commons Attribution 4.0 International License. The images or other third party material in this article are included in the
article's Creative Commons license, unless indicated otherwise in the credit line; if the material is not included under the Creative Commons license, users will need to obtain permission from the license holder to reproduce the material. To view a copy of this license, visit http://creativecommons.org/licenses/by/4.0/ 